\title{
Joanne Limburg
}

$\mathrm{H}$ eat*

One thing they don't warn you about is the stockings. Thigh-length stockings, in this heat. When I tried to query them, the nurse said why, do you want deep vein thrombosis? and of course I don't, but really they're quite unbearable. They look perverse too, snow-white and gartered, $18^{\text {th }}$ Century harlot stockings. I think my husband likes them - I've just had a c-section, and this is how they're making him look at me. I've had injections, I can move now, why do I need them? When I get out of here I mean to complain.

Not that I've been moving for long. When they first wheeled us in here, they checked us both, finding my wound to be oozing and my child to be unsatisfactory. They stood round the bed and administered their sentences: my wound was not healing and I would have to hold still; my blood might clot and I would require the injections and of course the stockings; my son was cold and would have to be kept in a heated cot; also he was hypoglaecemic and in need of immediate nourishment which they could provide but I could not. Then they whirled about together like a tornado and whooshed him away to be fed. When they brought him back I was crying but he wasn't, and that was the wrong way round.

I suppose I ought to try to be a bit radiant. It could be so much worse after all: it's true that I can't feed my son, I can't even pick him up, but at least he's next to my bed where I can look at him. All the woman in the next bed has is a photo, a web of tubes with a tiny red face trapped in its centre. Her baby is round the corner, behind the double doors, where unripe babies are cultivated precisely, each in its private forcing-house. Meanwhile, out on the open ward, we are all of us - mothers, babies, staff, visitors - indiscriminately baked.

It's close on midnight. My husband has gone, I've taken my evening pills and now I'm supposed to sleep. After three days awake it was easy enough to let them take the boy to the nursery: right now I need to sleep more than I need to feel like a mother. Now if only I could get comfortable. I've mentioned the stockings and the heat, but there's also the noise, the lights which never quite

\section{Joanne Limburg, Heat}

Studies in the Matemal, 3(1), 2011, www.mamsie.bbk.ac.uk 
go out, and then the other insults to my person: the sticky bleeding and the brick-sized maternity pad; the wound that cries out every time I shift position; the catheter tube running out of my body, out through one leg of my sweaty knickers over the side of the bed and down to a seethrough bag full of my urine, which hangs swinging from a frame. Every now and then a member of staff will inspect it and tell me I'm ketonic - or OK. My urine speaks to them more clearly than my words, which never seem to get my point across. But now I'll have to try again: I see my bag needs emptying. I ring the bell.

A few minutes later someone arrives, a night person, someone I haven't seen before. She is middle-aged, solid, implausibly blonde, and fed up with me already. What is it? she wants to know. I say my bag needs emptying. She looks and seems surprised to find that I'm telling the truth. She wants to know why I can't do it myself. I say that no-one has shown me how. She tells me to follow her to the toilets and marches ahead, while I stumble behind, bent almost double with my pissy burden. When we get there she tells me to watch as she detaches the bag from its frame, holds it over the bowl, unfastens the top and upends it. The sick yellow hours drain out. As easy as that, she says. I'll leave you to finish up. And she goes.

After she's gone I close the toilet lid and sit down for a few minutes. I feel surprisingly awful. I unbutton the deep placket of my nursing gown and look down at myself. I can't see anything I recognise. Here are two huge breasts, still uselessly stoppered, below them a ruptured, swollen belly with its stitch at the bottom like a drawstring handbag upside down, then the sweaty knickers and maternity brick, the catheter line, finally the harlot stockings, now with a torn toe on one foot and a bloodied toe on the other. I'm a walking aftermath. There's a mirror here, but I don't so much as glance at my face.

It's takes me a while to gather my aching parts together and get them all out of the bathroom. When I do, I find myself looking into the nursery, where my son is spending the night. They have the lights on full in there, and from the half-dark of the corridor I feel like a voyeur looking from the street into someone else's living-room. There are no mothers in there, just the babies lined up in their cots and the staff, bending over them. The solid blonde is one of them, she is saying, Which one do you want, June? June is a little older, I think, quite near retirement age, and an honest steel grey. Her eyes flicker greedily from cot to cot. Oooh, she says. I don't know... Then she points: this one. Ooh you beat me to it, says a russet-haired nurse, as she comes up

\section{Joanne Limburg, Heat}

Studies in the Matemal, 3(1), 2011, www.mamsie.bbk.ac.uk 
behind them. She's a sweet little lady, isn't she? I suppose I'd better feed that noisy boy over there - she points to a cot in one corner, which has a sad little wailing noise spiralling out of it. Then Steel G rey looks up, and our eyes lock. D o you want anything? she asks. Her voice is hard suddenly. No, I say, but then I think that this might be an opportunity, and I should make use of it somehow. Well, actually - I look down at my open placket - I should like to try and feed him? In the morning? They look at each other. Make sure you're ready at seven, says the blonde. Seven sharp, mind - you mustn't let the feeds slip back. I thank her profusely, for what she has conceded me, and shuffle away.

I don't believe I'll go to sleep but I do, lying on my back with my stockinged legs splayed and the tube running over one thigh. At some grey hour or another I am woken by a thud. I pull myself up a little and see that they are moving a bed into the curtained space across from mine. There is a head propped up on the pillow facing me, and a pair of arms holding a tiny baby, which is eased out of them and placed in a cot next to the bed. The woman is asked something, she answers and then the baby is wheeled away. Her eyes meet mine and she smiles weakly. My eyes are irresistibly heavy but I think I just about manage to return her smile before I find myself falling back again.

My eyes snap open in daylight. I pull myself up, slowly. I'm sweaty and rumpled and I need a change of maternity brick. Maybe clean my teeth too. I remember my date with my son and drag myself and the catheter bag round to the toilet to get ready for our first feed - sleep has refreshed me and I feel ready for him now, excited even, like a bride. When I get back to the bed my new neighbour is still fast asleep. I see that she is very young, and pale. I sit down on the bed and wait for my son to be brought. It is five to seven.

Eight minutes pass. I start to wonder if something might be the matter, and decide to go to the nursery. As I arrive in the doorway, I see that ash-haired June is sitting with him propped up on her lap, while she feeds him from a cup. She looks up at scowls at me. He's here and he's coughing up mucus, she barks. I feel that I am required to account for this, and remind her that he was a caesarean baby, and I can't help the mucus. I add that I was meaning to try and feed him. I know but you weren't on time, says the solid blonde, coming up behind June and my boy.

\section{Joanne Limburg, Heat}

Studies in the Matemal, 3(1), 2011, www.mamsie.bbk.ac.uk 
You can't let the feeds slip back, we did tell you. I open my mouth to say that I thought they would bring him but I see that their faces are walled over and it would be no good. I close my mouth. Are you going to come in? asks June, a bit less unkindly.

I step across the doorway and the first thing I notice is that the nursery is cool, blissfully cool, as if the staff have drawn all the cold air from the rest of the ward and are saving it here for themselves. (Still, they have red faces, some of them, and pit stains.) O oh it's lovely in here, I say. They don't respond. Instead June asked me if I've seen the chart yet. I shake my head. She returns my son to his heated box and picks up a chart which hangs off the end. He must be fed every two hours, she says. Mark it here, see? The amount - that's $10 \mathrm{ml}$ for now - and that's the box for who fed him. When you do it, you write 'Mum' there. A nappy change and a feed every two hours. She hands me the chart. I look at it and then hang it up again. Are you leaving him or taking him with? she asks. I say with and go to his cot. I notice it's plugged into the wall and ask for help to re-set it. They raise their eyes at my demands and once more I find myself struggling behind Solid Blonde, who propels the cot in front of her as if it were a trolley full of brushes.

It's one o'clock. My husband - who catches on faster than me - has changed the baby's nappy, cup-fed him under supervision from a nurse and gone to have lunch on the concourse. My catheter has gone, finally, and I'm sitting up on my bed drinking coffee and inspecting a breast pump, which a midwife has just shown me how to use. I can't decide whether it looks more like a flower in a jar, or a klaxon, and I am also thinking about all the kit here, the cups, the heated cot, the tubes and bags and pumps, all the impedimenta piling up between my body and my child's. It's overwhelming me, it makes me tired. I put the pump back down on my table and then I notice that the woman in the bed across from mine is getting up.

It's a slow, painful business and I can see why: she has the white stockings too, and the crunched-in-the-middle look of a c-section mum. When she has both feet on the ground, she comes towards me, holding her belly, and wincing all the way. When she has said hello she points to the pump. They showed me one of those, it's horrible, are you really going to use it? Yes, I reply, I want to try and get some milk out. She pulls a face. I couldn't, I just couldn't. They were on at me all the way through the pregnancy but I don't see why, I said I'm going to bottle-

\section{Joanne Limburg, Heat}

Studies in the Matemal, 3(1), 2011, www.mamsie.bbk.ac.uk 
feed mine but they won't leave me alone. Then she takes a sharp breath, hugs herself tighter and I think she might cry. Is it really bad? I ask. She nods. I say you could ask for stronger painkillers. She pulls another face, then she looks around and leans forward. Are you joking? They offered me and I said I'm not taking any of your pills. But they work, I say. She lowers her voice. D on't take them, it's neat heroin, they just want to keep us doped up. You should do what I do: I'm going to fatten mine up as fast as possible so he's up to weight so I can get us out of here. Then I can do what I want. She straightens herself up, and almost whimpers with the pain. Well I'm off to the shower, she says. I watch her go, and feel sorry for her. It's no good being paranoid in a place like this, it only makes things worse.

My neighbour has her plans, I have mine: I will pump to get my milk to start, and I will breastfeed, and when the staff see what a good mother I really am they will hand me my baby and wave us all goodbye. But it's not going well. I pump and pump, and all that comes out of me is blood and sweat. You wouldn't believe how much sweat: it soaks through my knickers, mingles with the blood on the brick, flattens my hair to my head and collects in viscose puddles under my breasts. My husband is no better off, a shining face over a clinging shirt, while the staff broil in their stiff tunics. Meanwhile my son drowses placidly on his warm mattress, wrapped up in three layers of clothing with a blanket over the top, and still they say he is too cold.

I suppose I can't blame him for his lack of interest in my breasts, what with his coldness and sleepiness, and their hopeless lack of productivity. Every feeding time, I hoist him onto me, and I try to get his mouth to meet my nipple. He sucks a couple of times, comes off, squirms, cries a little. I try again, he won't have it. I try on the bed, I try sitting up in the chair, I try with a pillow, with two pillows; staff come in and give us advice, sometimes they force us together, they hold his hands behind his back and say what trouble boys can be, what an awkward little tinker he is, a naughty boy, a silly little so-and-so, a toerag. My husband encourages. I sweat, then I give up. My husband gives him his cup feed, $20 \mathrm{mls}$ now, which he takes like a lamb. O ne of the nurses says, you see how easy that is, why work so hard for a tiny bit of mummy?

You're a wonderful mother, my husband soothes, when I cry. Look how hard you work - I don't see her working so hard. He nods towards my neighbour, who is feeding her baby across the way. She has him lying on his back on the bed, while she sits up facing him, pushing an almost-full

\section{Joanne Limburg, Heat}

Studies in the Matemal, 3(1), 2011, www.mamsie.bbk.ac.uk 
bottle into his mouth. That's far too much, my husband whispers. That'll all come back. When she has finished, she gets up, puts a handbag over her shoulder - she is dressed now - and pushes her baby into the nursery. There she goes again, says my husband. Why does she keep leaving the baby like that and going out? I thought you said she didn't trust the staff. She doesn't, I say. She says they put dope in our food, so she eats on the concourse. That's why she's always out. My husband shakes his head. Poor soul, she's mad as a bag of cats. I wonder how long she'll keep that baby?

On the third evening, with my agreement, my husband goes home a little earlier, to have something decent for supper: all the burgers are making him constipated, he says. There's no-one to watch the baby while I go to the toilet, but a nurse tells me not to worry, they can see him OK from the station, he won't be stolen away in five minutes. But when I get back there is a space where the cot should be.

Oh God no oh God... Maybe someone came in with a fake uniform, some mad woman without a baby, and they believed her and she took him. I shall have to smile bravely at a press conference, still in my nursing gown and wearing my wretched stockings. Or maybe - and this seems more likely - he's worse than they thought, he's behind the double doors, they're threading him with wires... Yes, I'd better go. And I run, even though it hurts, I run round the corner, my stockings falling down to my shins, my dressing-gown flying behind me, and then I stop. There is a gathering in the nursery, a few nurses, a couple of doctors too, and all of them are standing round my son's cot. No-one sees me but I go in.

- $\quad$ just in case, a doctor is saying. Then a nurse sees me. She's one I've only seen today, another older one, with 1950's schoolmarm glasses and a swimming hat of white hair. I don't like her: half an hour ago, when she helped us with the feed, she took my baby on her lap, she turned her back on us and did things to him, then she put him back in his box and left without a backward glance, without a word. Now she says that's the mother, there.

They all turn round. Come in, says the doctor, the tall woman who was talking when I arrived. Sorry we took your son like that, but we were all free now and you weren't there to ask. Now there's no need for you to be scared, but the thing is...

\section{Joanne Limburg, Heat}

Studies in the Matemal, 3(1), 2011, www.mamsie.bbk.ac.uk 
... they are going to have to do more to my baby, she says. The swimming hat nurse has seen him making movements with his arms - and she shakes her hands around like a funny string puppet - which mean perhaps he is not being nourished enough and so they are going to have to put a tube through his nose and down into his stomach to feed him. Also as a precaution they must test for infection which means a blood test and - she's sorry about this - a lumbar puncture; also just in case he'll need some doses of antibiotics, which he will be given intravenously. They are going to have to take him away now to do the lumbar puncture, to put the cannula into his arm and to give him his first dose. They take him away. Don't look so worried, says swimming hat. Go back to your bed and have a cup of tea. We'll bring him back to you when we're done.

They do return him to me, as they have promised to do, but they return him transformed. Sleepy still, and bundled, but with extra, plastic parts. There is a tube running out of his nose, the first couple of inches plastered to his face, and the rest hanging loose, stoppered at the end. The back of his right hand and half his forearm have disappeared under the bar which holds the cannula in place, and this in turn is held in place by a bandage, the whole assemblage inadequately covered by the hand-knitted yellow cardigan which I have already come to hate but now loathe even more. He wakes a little, and for a moment waves the arm around incontinently, like a fiddler crab claw, whacking it painfully against the cot-side as he does so. I wince, but he quickly settles down again.

Swimming-Hat stays with us after the doctors have left. She picks up the feeding chart and says it's time for a feed, she'll show me how to tube feed. She goes to fetch his $20 \mathrm{mls}$ infant formula, while I sit and contemplate the latest version of my son, this hospital's child with his customfitted orifices. When she comes back, she has a small bottle of formula and a syringe. Watch carefully, she says, as she takes the stopper off the end of the tube. Now this is important, before you give him anything new, pull the plunger back like this, just to make sure there isn't too much left in the stomach from last time ... nothing... Good. Now you take the plunger out, pinch the tube closed - did you see that? Pour a little in, let the tube go - see it draining? - hold it up, you need the gravity - now as it drains pour a little in - don't let it get empty while you're feeding, he'll get air in the stomach - a little more... there, all done. Do you think you can do that?

\section{Joanne Limburg, Heat}

Studies in the Matemal, 3(1), 2011, www.mamsie.bbk.ac.uk 
I nod. It looked hateful, I don't know how he slept through it all, but as I might've expected, he didn't make a squeak. I must look miserable because she adds, It's better like this for now: you're getting the nourishment in, he'll get stronger, get a stronger suck. She touches my arm, briefly. You'll get used to it, all right? I don't nod this time, but she goes. I look at him, this not-my-son, and wonder what I'm allowed to do. He looks all the more fragile now they have perforated him. I reach out and gently, gently stroke his head with my fingertip, one, two, three times. He lies there peacefully, breathing with luxurious slowness. I phone his father on the extortionate bedside phone, to tell him what has happened. Then I sit for a while, maybe half an hour, and watch my son breathe. I don't pick him up and cuddle him as I know it's not allowed. Then I push him to the nursery and go back to bed to get what I can of my night's sleep.

I gather up my bathroom things, my toothbrush and toothpaste, my towel and face wash, some cotton wool to wash my bloody self and the garden-variety sanitary towel which by now - praise be - I am able to use instead of the punitive maternity bricks - and as I do so I see my neighbour coming back from her bathroom visit. She has a thick winter dressing-gown on and bizarrely, big furry slippers. She catches my eye and nods, then takes a peep over her shoulder and shuffles over. I brace myself as she comes closer, closer, until she is so close to me that I can smell the toothpaste on her breath, until her face is all I can see. When she starts to speak she lowers her voice so much that, even though we are almost touching, I still have to concentrate to hear her.

You poor thing, she murmurs, sounding sad, but at the same time somehow excited. And that poor little mite of yours - they really got him didn't they? Full of tubes, I don't know when you'll get out now, they'll have you for months I reckon. Sneaky wasn't it, the way the took him when you couldn't stop 'em? I bet you would've stopped them. I would've held mine tight and screamed. Why are they doing it to him, what did they tell you?

They thought he was going hungry, I say.

What with a good mother like you? Don't you believe them, it'll be one of their experiments. Poor wee mite, poor little innocent -

\section{Joanne Limburg, Heat}

Studies in the Matemal, 3(1), 2011, www.mamsie.bbk.ac.uk 
Are you sure? I manage.

Oh yes, I'm sure, I know - they need our babies, they want 'em alive, and they want 'em dead. I know because they got one of mine.

I open my mouth and close it again. My eyes are filling with tears. She carries on.

You know those two towers we can see out the window? I nod. The incinerators, I say. For clinical waste. Clinical waste, she repeats. That's what they call it. My other baby went in there. I was twelve weeks, they scan him, they say to me, sorry he's no good, then they flush him out of me, I don't see him again, but I figured out why - they used him - and when they used him all up he went up that chimney. And I'm going make sure they don't get my other one - oh they let me carry him this time, but will they let us out? You're lucky you've got a husband, a family - they won't kill yours at least, they'd never get away with it - but my boy's got no-one but me, and I've got no-one at all.

I'm so sorry, I say. I had a miscarriage too. I know how much it hurts.

She doesn't seem to hear me. She stops for a moment, and stares into the blind that covers the window at night. Suddenly she asks, are you church-going? I explain that I'm Jewish. Well never mind, she says. God loves you anyway, and I'll pray for your child. Good night.

I'm shaking as I go through my bathroom routine, as if I've been in an accident. She's filled me with her madness, and I want to get away from her; I wonder how I might ask to be moved without the staff asking me questions I find I'm afraid to answer. I don't expect to sleep after our conversation, but once the initial agitation has stopped, I realise I'm drained, and I fall asleep so quickly that I can feel myself plummeting.

It must be the heat that wakes me up. It seems to have got worse. It sits heavily on my chest, and I struggle to pull myself up. Sweat pours into my eyes, making it hard to see. I start to wipe it off with my nightgown, but that is soaked too. I decide to go to the bathroom, splash some cold water on myself; then I will change into my other nightgown. With immense difficulty, I haul myself off the bed and ferret about for the clean nightgown and my towel.

\section{Joanne Limburg, Heat}

Studies in the Matemal, 3(1), 2011, www.mamsie.bbk.ac.uk 
I can't find them, but I can't bear to stay this uncomfortable so I start heading for the bathroom anyway. It's slow because of the heat, which has turned the air red, and is warping space and time so that just as I think I've reached the corner next to the nursery I find that I'm really back at the bed again. After a few false starts like this I reach the nursery. As before, it looks utterly different from the rest of the ward. It's cooler in there, so that light isn't the thick red shade that it is out here; instead it's a cleansing blue-white. Again I see the rows of babies in the cots, and again the staff. Some are bending over the cots, others are sitting in the nursing chairs, feeding several babies at once, with breasts and bottles. I see with a pang that one of them is suckling my own son, but still I stand there and say nothing. I realise that I knew this all along - who the real mothers are here, and that this is the way it has to be. What good am I, who am empty?

There is one good thing about this, I realise, and that is that, if I'm not to be his mother, then there's no need to wear the stockings any more. I peel them off, then I ball them up and throw them to the ground, as hard as I can. For a moment, I feel absolute bliss. But then I become aware that I have done a very bad thing, something that will lead to terrible danger. And yes, the wailing is beginning, quietly at first, from inside the nursery. I begin a panicked search for the stockings, but I have flung them too far away, they have rolled to the ends of the earth already, and now my baby is for the chimney.

My eyes open suddenly and completely, like the eyes of a doll stood upright. I am lying face-up on my bed, the heat has subsided from equatorial to its usual sub-tropical intensity, the light is grey-ish, and my stockings are on. But the wailing hasn't stopped. At first I think it's me who's screaming - which would make sense after all - but I realise that the sound is coming from a little way away. From my neighbour, in fact. To make certain, I creep out of bed and pull the curtain aside a little. Hers are drawn tight, with yellow light from her bedside lamp seeping under them. The wailing quiets a little and I can hear other sounds coming through the curtains, a busy shuffling and a low voice, calm and brisk and perhaps a little admonitory - the voice of a nurse or midwife. Then a member of staff - she's dressed in her own clothes, it must be a midwife comes out and sees me. Everything's fine, she says. Go back to bed and go to sleep. I do as I'm told.

\section{Joanne Limburg, Heat}

Studies in the Matemal, 3(1), 2011, www.mamsie.bbk.ac.uk 
When I wake up I am conscious of a new source of discomfort, and know that in some way I have changed again. As I pull myself into a sitting position I realise that it is my breasts which are different: huge and hard as rocks. When I touch them they feel sore, and are covered in nasty lumps. It isn't that I don't know what this means, but it frightens me all the same and I begin to sob, louder and louder. The curtain is pulled back, a midwife's face appears and asks what the matter is. I say that my breasts hurt, and are covered in lumps. Her face breaks into a smile. Congratulations, your milk has come in. That ought to help matters. I know, I say. It's just it felt like too much. Hormones, she replies: textbook baby blues, goes with the territory. Y ou'll start to feel much better soon. $\mathrm{OK}$ ?

I gather up my morning things and open the curtain. To my surprise my neighbour is up and dressed already. Her curtains are drawn right back to the wall and she is sitting calmly on her bed, painting her toenails. Her baby sleeps in the cot beside her and there is an emptied bottle of formula sitting on her bedside table. She looks up and smiles. O h hello, what was up with you? You sounded like you were having a breakdown or something. My milk's come in, I said. It took me by surprise, I suppose. So did the crying actually. She makes a knowing face. It's a woman's job to weep, she says. I can only agree with her.

I move a bit closer to her bed. And what about you? I ask. I heard you last night, there was some kind of emergency. Her face takes on the furtive look that has become so familiar, and she lowers her voice. I had pains, she said. You know the womb has to go back down? Because I'd been moving around so much it happened all at once, last night. It was horrible, like the labour pains again. I didn't want them to but they gave me something, they made me have an injection. Did it take the pain away? I asked. She pulls a face. Not really, but it made the pain seem far away. I didn't like it, they drugged me, they got me when I was weak... But I don't care what they say, I'm getting out of here soon. She picks up the empty bottle and waves it. See? Eats like a piglet, this one. He'll be putting on weight like nobody's business!

My husband arrives to find me pumping. With cautious triumph I hold up the bottle, which has a tiny puddle of milk at the bottom. I can make a thin stream come out from just under each nipple! I say, a bit too loudly. He shushes me. That's wonderful dear, he says. But I don't think

\section{Joanne Limburg, Heat}

Studies in the Matemal, 3(1), 2011, www.mamsie.bbk.ac.uk 
everyone needs to know. So your milk's come in at last. Yes, I say. Things can only get better now - can't they?

And they do, but slowly. First of all, oh wonder of wonders, they let me take the foul stockings off. Really they can't have been doing me any good for days now: they have quite lost their elasticity, and have been bunching sadly around my knees. When one of the nurses says that I can remove them, I ask what I should do with them. Oh keep them, she laughs. We don't use them again. You could use them on your next long-haul flight, couldn't you? I look at them, at the greyish, bobbled weave of them, the hole in the sock, the bloodstain. Actually I'm scared of flying, I tell her. Please take them away. You can burn them in your chimneys. She looks a bit taken aback, then decides that I must be joking and laughs as she takes them from me. Bye bye stockings. You can burn in hell now.

Funny what passes for happiness in a place like this. To feel the air moving round my legs albeit the warmed-over, almost-foetid air of the ward - is an indescribable luxury. The drawing of $5 \mathrm{mls}$ of thin white milk from a breast is the greatest thing I have ever achieved. As I pour it into the syringe and watch it drain into my son's stomach, I feel as if I have claimed a small part of him back.

But it is the smallest part. My son is beginning to wake up to the world at last and I know that it is the hospital staff, with their adjustable equipment and measured doses, who have succeeded in rousing him. If anything, I have been in the way. But now, twenty-four hours after it went in, they are pleased enough with him to take the feeding tube out. He is even warm enough, at last, to be moved into a normal cot. I am full of resolve and good milk, and now I will be his mother.

As I said, my son is waking up to the world. He has desires, preferences and opinions. His hunger is a rage that takes over his face, until it is nothing but a pair of screaming concentric circles. The screaming face bobs desperately along my husband's arm; it latches onto his bottom lip, his chin. When the face is brought to my breast, though, the screaming only increases. I am a source of frustration to him, and only the cupped formula can bring relief. I realise that I can never be his mother while the hospital holds us both in its sweltering cradle. The stockings may be gone but the heat remains, covering me all over in a sweaty film.

\section{Joanne Limburg, Heat}

Studies in the Matemal, 3(1), 2011, www.mamsie.bbk.ac.uk 
My body repulses me, so I don't blame my son for turning his face away. Plastic must seem more reliable to him than my ever-altering clammy breasts. It makes sense when the nursery nurse, during one particularly agonising feeding session which has left us both in furious tears, leaves and comes back with a floppy, clear teat. A nipple guard, she says. I know a lot of midwives hate it but anything's worth trying, hey? I slip it over my nipple. It's a miracle: now that my son has something artificial to hang on to, to shield him from my disturbing flesh, he latches. Now how's that? she asks. That's wonderful, I say gratefully, as I feel the crunch in my womb that tells me this is real.

The next morning, they tell us that all the cultures are negative. They weigh my son, take his temperature and are pleased. Once the paperwork has been done, we can go. I can hardly believe it.

My neighbour is going too. We sit facing each other like two smiling book-ends, sitting crosslegged on our beds, in our clothes. We have even done our hair the same way, in French plaits of course it makes sense, in this heat, to scrape it all back from one's face. She leans towards me, as if to start a conversation, but gets no further because at that moment one of the midwives arrives with my discharge notes and my drugs. She pulls the curtains round and explains everything to me: there are drugs for my pain, my private supply of what has been doled out on the ward, the white paracetamol pills and the stronger, pointed brown ones; there is a big box of iron tablets, to replace what I lost during the birth and am still losing now; there are leaflets on feeding, on crying, on regulating my child's temperature, on safe sleeping positions and the best ways to avoid cot death. When she has finished she asked if I have any questions and I ask if the community midwife will be taking my stitch out after I get home.

Good God! she says. Your stitch! That should've been out days ago! How negligent of us, I'm so sorry, just wait a moment. She goes and comes back with a pair of scissors. Are you ready, she asks? Now I'm afraid this will sting. She snips the bead off one end of the long, single stitch and pulls. It is astonishingly bad - a searing, ripping sensation. I suck my breath in hard. Well done, she says. You poor thing, that really shouldn't have been in so long. I examine my wound, an angry red seam.

\section{Joanne Limburg, Heat}

Studies in the Matemal, 3(1), 2011, www.mamsie.bbk.ac.uk 
My husband takes the luggage down to the car first. He has quite a lot to carry, what with my drug supply, the new nipple guards and pump from the hospital shop, the carrier bags of free samples I had thrust on me, the two pillows we brought with us for the labour, the new clothes I bought during my pregnancy, which have turned out to be optimistically small, the maternity clothes which I have been wearing instead, the books I haven't opened, the breast pads I haven't leaked enough to need and the leftover maternity bricks. I have shoved most of it into the blue zip-up hold-all we bought especially for the hospital stay, and which I mean to throw away at the first possible opportunity. I have seen all I ever want to see of it.

When all this paraphernalia has been stowed in the boot, my husband returns with the new car seat. He puts it down on the floor by my bed. He looks at the baby, who is sleeping in his cot, and then at me. I look at the baby, and then at him. He picks the baby up and straps him into the seat, gently, taking the greatest care, so that the baby does not wake up. Have you got everything? he asks me. Have you checked round the bed? I say yes, he lifts the baby in the seat, and we leave. As we pass the nursing station, the staff wish us good luck with their brisk best voices, while their eyes say remember you are on probation.

Another thing they don't warn you about is how it feels to leave hospital. That the world outside the ward will have got so much bigger and noisier since you left it; that you can't remember how to be in it any more. That when you arrive home you will feel lost, bereft of the charts and temperature measurements, of the routines and the voices over your shoulder telling you what to do, of the uniformed people who alone can protect your child from your mistakes and you from yourself.

This first evening home has been dreadful. My son refuses to settle, and he won't latch. I think he feels lost too. I think he wants to go back to his nurses, their crisp uniforms and their clean smells. He must miss their brisk ways, their deft displays of mastery with nappies and plastic cups. They always knew what to do. Now here he is crying, he is crying and crying and all I know how to do is to cry with him. My husband is losing patience with me. When the microwave pings

\section{Joanne Limburg, Heat}

Studies in the Matemal, 3(1), 2011, www.mamsie.bbk.ac.uk 
to tell us that the pump is sterile again I can see how thankful he is for the excuse it gives him to leave.

Left alone together, my son and I carry on with our grieving. We catch each other's eye, and our screams increase, as if neither of us can bear what we see: the horror in his face, the helplessness in mine. He needs a nurturing body to hold him, and all he has is this snivelling sack of pain. My breasts are sore, my head aches from constant crying and my wound is angrier than ever. The redness is seeping out of it now, spreading out over my stomach and mons veneris. It carries in it the sick heat from the hospital, which throbs through my body. Or maybe it was my heat all along. Maybe my milk is curdling inside my breasts and will make my son ill. It is only right that he doesn't take it. He knows. He knows that I am being tested, he knows that I am failing; he knows that for this I must burn.

* $\bar{\oplus}$ Joanne Limburg, $\mathrm{H}$ eat: an unpublished short story. Contact the author on joanne@ madrigal.demon.co.uk 